\title{
Public Sector Provision of Free Agricultural Inputs in Uganda: The Rationale and Challenges of Operation Wealth Creation Programme
}

Tabaro Robert (Corresponding Author)

Kyambogo University

P.O Box 01, Kyambogo, Uganda

Katusiimeh Mesharch

Makerere University Business School, P.O Box 1337, Kampala, Uganda

Received: April 5, 2018 Accepted: May 9, 2018 Online published: May 25, 2018

doi:10.5296/jpag.v8i2.13196

URL: https://doi.org/10.5296/jpag.v8i2.13196

\begin{abstract}
The paper analyses the rationale and challenges of public sector provision of free agricultural inputs in Uganda focusing on Operation Wealth Creation (OWC) programme. The programme officially started in 2014 and targets subsistence farmers in the country. OWC aims at commercialization of agriculture thus creating wealth and reducing poverty. It uses the military (Uganda Peoples Defence forces) to distribute and supervise delivery of inputs on the assumption that the army is efficient, organized and disciplined. The study was conducted in the new district of Sheema using purely a qualitative approach. We interviewed farmers, local leaders, opinion leaders and central government officials (key stakeholders) and conducted two Focus Group Discussions. Observation was also used to see how input distribution was being done. Our findings revealed that although OWC is well intended (creation of wealth and reduction of poverty at household level), it faces numerous challenges that hamper smooth implementation. The most common identified challenges were: small quantities of inputs supplied due to limited budget, poor quality inputs, elite capture and stringent entry requirements. Others are fear of the military by farmers, late deliveries of inputs and poor information flow between suppliers, district leadership and farmers. We recommend that government should increase agriculture sector budget, improve on quality of inputs and information flow between suppliers, district leaders and farmers but also fully
\end{abstract}


involve the district leadership in programme implementation.

Keywords: public sector, agricultural inputs, operation wealth creation, Uganda

\section{Introduction}

In Uganda like many other African countries, agriculture forms the backbone of the economy and close to $80 \%$ of all households in the country are involved in agriculture (UBOS, 2016). The sector contributes to over $70 \%$ of export earnings (World Bank, 2016) and accounted for $26 \%$ of GDP in 2013/2014 (MAAIF, 2015c). However, agriculture in Uganda is largely dominated by smallholder farmers who occupy the majority of the land and produce most of the crop and livestock products. They compose $85 \%$ of the total population in agriculture (Balya, 2010).

Masaba (2014) identifies some of the challenges to agricultural development in Uganda as high costs and limited access to improved farm inputs and production technology, lack of access to agricultural credit facilities and inadequate agricultural extension services. Additionally, Wandulu (2004) asserts that input use by smallholders in Uganda is among the lowest in the world far lower even than the African average. For instance, fertilizer use is at an average of $1 \mathrm{~kg}$ of nutrients per hectare well below the recommended standard of $200 \mathrm{~kg}$ by Abuja declaration of 2006 (DRT, 2012). Another serious challenge facing agriculture in Uganda is financing. While the agriculture sector received on average 4 percent of the government of Uganda financed budget in the early 1980s, the sector has rarely received more than 3 percent $^{1}$ of the budget in any year since 1991/92 (Smith et.al, 2007). In some years, the share has been below $2 \%$ although donor financing raises the allocation substantially but it has never exceeded 5 percent (DRT, 2012).

Distribution of agricultural inputs in Uganda is done using various approaches: public private partnership arrangements, community procurement like under National agricultural advisory services (NAADS), and Ministry of agriculture, animal industry and fisheries (MAAIF) through provision of seedlings; and the private sector and cooperatives (MFPED, 2014b).

From 2014, Uganda government embarked on the programme of distributing free agricultural inputs (seeds, seedlings, planting materials and breeding stock) to farmers known as Operation wealth creation programme (OWC) with the main goal of commercializing agriculture by creating wealth at household level and reducing poverty. The programme uses the army, the Uganda peoples defence forces (UPDF) to distribute and supervise delivery of inputs. However, as reports have shown (e.g. Parliament Report on OWC, 2017; Equal Opportunities Commission Report, 2016 e.t.c) the programme is facing many challenges that hamper its smooth implementation.

\footnotetext{
${ }^{1}$ This is below the 2003 Maputo declaration wherein African Heads of State and government committed themselves to allocate at least $10 \%$ of national budgetary resources to agriculture and rural development policy implementation within five years.
} 


\subsection{Emergence of Operation Wealth Creation}

OWC emerged as a result of restructuring the previous programme - NAADS. In 2001 government established the NAADS programme. It was established by an act of parliament (NAADS Act, 2001) to specifically address constraints to agricultural development including lack of access to agricultural information, knowledge and improved technology among rural poor farmers (Mugasi, 2017; MFPED, 2015). NAADS was also meant to promote the development of farmer organisations and empower them to procure advisory services, manage linkage with marketing partners and conduct demand driven monitoring and evaluation of the advisory services and their impact (Benin et. al, 2007:1).

The NAADS programme was to be executed in phases for a period of 25years. The first phase started in July 2001 and ended in June 2010. The $2^{\text {nd }}$ phase started in July 2010 and was meant to end in 2015 (Okoboi, Kuteesa \& Barungi, 2013) but the programme was restructured in 2014 before completion following a Cabinet directive to address key constraints of: inadequate inputs and technologies at farm level, delayed procurements, high costs of administering the programme and corruption (MFPED, 2015, Rwakakamba \& Lukwago, 2014). Henceforth, the implementation of NAADS activities ceased and all NAADS personnel in the District Local Governments (DLGs) were terminated (MFPED, 2015). The only remaining operations of the programme have now been limited to its secretariat in the capital-Kampala whose work is to purchase agricultural inputs for distribution to farmers (See also Oluka, 2016).

\subsection{From NAADS to OWC}

OWC is an intervention that President Museveni introduced and piloted ${ }^{2}$ from July 2013 to create a system that facilitates effective national socio-economic transformation with a focus on raising household incomes for poverty eradication and sustainable wealth creation (http://portal.defence.go.ug). As such, OWC has no clear legal status and its operations are funded by money budgeted under NAADS, a statutory body created by an Act of Parliament (Semujju, 2017).

On $9^{\text {th }}$ June 2014 during the Heroes day celebrations in Mityana district, central Uganda, President Museveni officially restructured NAADS programme. He opted to employ military men, the UPDF in the DLGs under a new programme - OWC who would ensure effective delivery of agricultural inputs to the beneficiaries and possibly reduce corruption that characterized the former NAADS programme (See also Ladua, 2015). Consequently, cabinet made the approval of the programme (OWC) on July $7^{\text {th }} 2014$ under minute number 186 (CT 2014). Under the directive of the responsible minister, the cabinet decision was implemented and over 300 UPDF officers underwent induction training course in Agriculture at Makerere

\footnotetext{
${ }^{2}$ Programme was piloted in the Luwero-Rwenzori Triangle and some parts of Eastern Uganda starting from 2013 (MFPED, 2015). These are some of the areas that had supported the military/political struggles that liberated the country and as such war veterans were meant to be the first beneficiaries. It was later rolled out to the whole country.
} 
University (Report of Parliament on OWC, 2017).

The overall goal of OWC is to enhance household participation in commercial agricultural production through community mobilization, equitable and timely distribution of inputs and facilitation of agricultural production chains (OWC, n.d). Focus was also put on reduction of subsistence farming by embarking on serious national socio-economic transformation of the country. The target beneficiaries are all farming households in addition to civilian veterans (MAAIF, Standing orders of procedure for OWC, 2015a). However, the specific target is the $68 \%$ of the farmers in the subsistence economy (Angina, 2017).

OWC programme basically distributes free agricultural inputs to farmers in the DLGs. The inputs include cash crops such as coffee, tea, citrus, mangoes, pineapples and apples. It also focuses on food security crops such as maize, beans, livestock and a smaller range of enterprises (Mugasi, 2017). Inputs are delivered in the months of March/April and August/September in the first and second seasons respectively (MAAIF, Standing orders of procedure for OWC, 2015a).

According to the MAAIF, Standing orders of procedure for OWC (2015a), DLGs are responsible for selection of beneficiaries. This should be done in a participatory process at the parish level at the beginning of every season at meetings presided over by the sub county chiefs, facilitated by agricultural technical officers and addressed by OWC officers.

The rest of the paper proceeds as follows; We first delve into the literature on why governments should intervene in the distribution of agricultural inputs and the challenges they face; we then present the research design. After we present the findings, followed by the discussion section after which we give the conclusion and some recommendations.

\section{Justifying Government Involvement in Supply of Agricultural Inputs}

Governments world over get involved in distribution of agricultural inputs to farmers either by giving subsidies, free (direct) supply or direct payments to farmers among other channels. Whichever means the government uses, intervention in distribution of inputs is always justified based on either the economic efficiency rationale or the allocation of income to a particular constituency (for reasons of social equity or political patronage).

Brodeur and Clerson (2015) state that from the perspective of having to feed the ever increasing world population (nine billion people by 2050) in conditions that ensure the sustainability of agricultural resources, government intervention remains relevant in the $21^{\text {st }}$ century. However, production can be boosted if governments support various yield enhancing efforts. Importantly, investment in research and development practices in order to increase seed varieties, seed resistant to pests or availability of high yielding seeds is one of such interventions (Akkaya, Bimpikis and Lee, 2016). Similarly, Jelic et. al (2014) argue that provision of more food can only be achieved by applying modern methods of farming and/or technologies (green revolution package). However, since this calls for more research in agriculture, the state should be included to fund research. On their own, small agricultural manufacturers may not do independent research in new technologies but even the large agricultural manufacturers would need the state to protect their rights (ibid). 
Government can also intervene in agriculture to offset high costs of supplying inputs. Wiggins and Brooks (2010) state that when potential input dealers know too little about the demand for inputs and suspect that demand may be low, they will not stock such inputs. The two authors further state that the little stock dealers may carry then has a high mark-up to cover both the risk of not being sold as well as high unit costs for transport and storage of small lots since scale economies are not achieved. Such challenges can best be offset by government involvement in the supply of inputs.

Further, government intervenes to make inputs affordable to poor farmers. Farmers especially smallholders lack the financial ability (Gordon, 2010) to buy inputs early in the crop season and cannot obtain credit from financial institutions or input dealers. Banks or input dealers will not offer credit if they do not know enough about the competence and character of farmers seeking loans, or will only do so if they can get collateral and character references, the requirements that many small farmers cannot meet (Wiggins \& Brooks, 2010). Without government involvement, poor smallholder farmers may not be able to access better and improved inputs.

Clark and Thompson (2011) argue that in Canada for instance, there are political and social reasons for government intervention in agriculture some of which have an economic argument. As the two authors show, policies undertaken by government are embedded within the overall political structure of the country with its regional characteristics and focus on questions such as national unity. Relatedly, Wiggins and Brooks (2010) note that politically, subsidies are a highly visible gesture to rural voters as well as potentially also being an instrument of patronage. For instance in Zimbabwe, the Operation Maguta programme was viewed by critics as inclined to partisan distribution of inputs (Mutami, 2015).

However, as Govere et. al (2009) note massive involvement of government in distribution of inputs may not be sustainable because of limited government budgets and the disruption of the growth of the private sector. They also add that there are other inherent inefficiencies that may lead to input distribution delays, limited choice of inputs, lack of quality assurance (thus poor quality) and the misallocation of scarce resources due to poor targeting and leakages.

\section{Challenges Associated with Governments' Provision of Agricultural Inputs}

In many African countries such as Malawi, Zimbabwe, Tanzania, Ghana and Uganda, national governments have involved themselves in the distribution of agricultural inputs through a number of programmes and/or initiatives. Literature has, however, shown that many of these programmes failed to achieve the intended purposes due to a number of challenges.

Zimbabwe government in 2005 launched the Operation maguta programme as an input distribution scheme run by the Zimbabwe National Army to boost agriculture production and food security and by extension ensure a stable security environment in the long run (Mutami, 2015 and Pazvakavambwa, 2009). However, as Mutami (2015) shows, critics of the programme pointed to the partisan distribution of inputs, particularly in communal areas. Also, officials from the ministry of agriculture felt that they were supposed to run the 
programme since they had structures in farming communities who could distribute the inputs efficiently as opposed to the army. According to Pazvakavambwa (2009) the Operation maguta programme was grossly abused which resulted in the squeezing-out of genuine farmers, secularized input distribution and the diversion of inputs to the black market by unscrupulous profiteers.

Schiesari, Mockshell and Zeller (2016) on their part state that the government of Malawi in 1993 started to distribute free inputs at a national level, which led to the creation of the Starter park programme in 1998. Under the project, government distributed fertilizers and seeds to plant 0.1 hectare of land to every smallholder, free of charge. However, the project became costly, not efficient in targeting poor farmers and also displaced private input sellers.

Similarly, in 2005/06 agricultural season, the Malawian government introduced the Agricultural Input Subsidy programme to provide maize seeds and fertilizers to smallholders farmers at subsidized prices. The agricultural input subsidy programme targeted smallholder farmers who were resource-poor but owned a piece of land. Also the programme targeted special vulnerable groups (Chirwa, Matita \& Dorward, 2011). However, as Wiggins and Brooks (2010) show, targeting was imperfect and some of the vouchers were distributed to political supporters. Additionally, the cost of the programme rose as well to more than USD 200million during 2008/09 representing $16 \%$ of the total government budget (Wiggins and Brooks, 2010). Mvula et. al (2011) add that there were some village heads that were not too clear on the criteria and they often added their own criteria to the list which resulted in them forcing genuine beneficiaries either to miss out on the beneficiary list or to share the coupon with people that should never have benefited at all.

In the evaluation of four subsidy programmes in agricultural input distribution in Africa (Malawi, Zambia, Ghana and Tanzania) Baltzer and Hansen (2011) state that most of the programmes experienced serious delays and uncertainty in the delivery of inputs to farmers mainly due to administrative challenges which could lead to severe consequences for programme efficiency and sustainability. Lastly, in Zimbabwe, Pazvakavambwa (2009) says under the Subsidized fuel for farmers initiative, there was no monitoring and follow -up in the field to ascertain that fuel had been used for the intended purpose.

\section{Research Design}

This is a cross-sectional study design. The study is purely qualitative and used interviews, focus group discussions (FGDs), observation and document review to collect data. We employed multi-stage cluster sampling method to select the study area (administrative units) but used purposive and snow ball (non-probability) methods in selecting respondents.

Data were collected from the new district of Sheema in western Uganda (created in 2010). Sheema district has three constituencies (Sheema North, Sheema South and a Municipality). Using an online random number generator, we selected Sheema North for our study. We opted for one constituency so as to have an in-depth understanding of issues in the study area. From the five sub counties and/or town councils of Sheema North, we selected one town council (Masheruka). From the five wards that form the town council, we selected two wards 
(Kabustye and Nyakambu). Finally, from each of these wards, we selected two villages. All the administrative units were selected using an online random number generator.

Our target population were farmers (beneficiaries and non-beneficiaries ${ }^{3}$ ) and other key stakeholders in the programme both at the local and central government level. Thus at central level we interviewed NAADS and OWC staff, members of parliament (MPs), ministers and staff in agriculture ministry. At the local level, we interviewed political leaders, chief administrative officer (CAO), Resident district commissioner (RDC), production officers, town clerk, town agents, OWC coordinators, opinion leaders, beneficiaries and non-beneficiaries.

Table 1. Category and Number of Interviewees

\begin{tabular}{|c|c|c|c|}
\hline $\mathbf{S} / \mathbf{N}$ & Category & Frequency & Data collection method \\
\hline 1 & Farmers & 86 & Interviews \& FGDs \\
\hline 2 & $\begin{array}{l}\text { District and other local } \\
\text { leaders }\end{array}$ & 14 & Key informant Interviews \\
\hline 3 & Opinion leaders & 3 & Key informant Interviews \\
\hline 4 & $\begin{array}{l}\text { Ministry officials and } \\
\text { MPs }\end{array}$ & 11 & Key informant Interviews \\
\hline 5 & OWC officials & 6 & Key informant Interviews \\
\hline \multirow[t]{2}{*}{6} & NAADS officials & 4 & Key informant Interviews \\
\hline & TOTAL & 124 & \\
\hline
\end{tabular}

Source: Field data

Programme beneficiaries were selected using the lists from the town council and we traced them from the selected villages. For the non-beneficiaries (who had tried and failed to access inputs), we used snow ball method. After identifying one in each of the selected villages, they would refer us to their colleagues whom they knew had too missed inputs. We engaged them in in-depth interviews until we could reach saturation levels. Other key stakeholders at local and central government level were purposively selected. We too organized and conducted two FGDs in the two parishes studied and also observed how distribution was being done. We were able to accomplish this using interview guides, FGD guide and an observation checklist.

\section{Findings}

According to officials at NAADS secretariat in Kampala, OWC is an initiative by president Museveni whose aim is to improve the livelihoods of the rural farmers (targeting specifically subsistence farmers) and is being implemented by the ministry of Agriculture, animal industry and fisheries (MAAIF) through its agencies such as NAADS, Uganda Coffee Development Authority (UCDA) among others in collaboration with the office of the president (army). As such, NAADS officials reasoned that OWC utilizes the relevant skill sets of UPDF staff including trained veterinary doctors, agronomists and entomologists among others. Additionally, UPDF officers who didn't have prior training in agriculture were later to benefit from a two-weeks induction training at Makerere University.

\footnotetext{
${ }^{3}$ We focused on non-beneficiaries that had tried getting inputs and failed. They could easily tell the challenges they met and why they missed.
} 
Discussions with some senior district officials in Sheema revealed that world over, agricultural subsidies or free input distribution to farmers for particular reasons (e.g. boosting agriculture production for food security and safety, increasing farmer incomes e.t.c) is a common practice. "What Ugandan government is doing is not unique to Uganda and should be appreciated" (District official). Other officials reasoned that OWC is a well-intentioned programme and if well-handled has the potential to pull millions of Ugandans out of poverty by the year 2020 .

\subsection{Challenges in the Implementation of $O W C$}

Programme implementation, as the study findings show is faced with a number of challenges as below.

\subsubsection{Limited Quantities, Poor Quality and Late Delivery of Inputs}

We established that the greatest challenge of the programme in Masheruka town council is limited quantities and poor quality of the inputs supplied. Officials at NAADS secretariat argued that limited quantities are attributed to the limited budget MAAIF and NAADS receive. "We have an overwhelming demand amidst limited budget" (NAADS official). Generally, agriculture sector in Uganda receives a small budget compared to many other sectors (e.g. Defence) yet agriculture is the backbone of the country's economy. In most of the cases, the sector receives less than $5 \%$ of the total national budget. For instance in the financial years, 2014/15, 2015/16 and 2016/2017, the percentage share of the agriculture sector against the total budget was $3.2 \%, 3.0 \%$ and $3.0 \%$ respectively (NBFP 2012/13-2016/17 and 2016/17-2020/21). Specifically, the NAADS budget is small although it has been increasing over the years especially from 2014 when the body was given a new mandate of supplying inputs through OWC programme. For instance, NAADS budget was 318.61 bn and 319.702bn for the financial years 2016/17 and 2017/2018 respectively (CSBAG, 2017). Given the fact that inputs must be shared amongst the 116 districts of Uganda, share per district is small.

Table below shows quantities of inputs supplied (nationally) and the discrepancies because of limited budget in 2015 . 
Table 2. Quantity of inputs distributed during the March-June 2015 (nationally)

\begin{tabular}{l|l|l|l|l}
\hline S/N & Input & Quantity needed & Quantity available & Discrepancy \\
\hline 1 & Coffee seedlings & $70,915,889$ & $37,000,000$ & $33,915,889$ \\
\hline 2 & Tea seedlings & $4,414,225$ & $28,000,000$ & $-23,585,775$ \\
\hline 3 & Mango Seedlings & $15,228,970$ & $1,085,000$ & $14,143,970$ \\
\hline 4 & Orange seedlings & $11,150,217$ & $2,800,000$ & $8,350,217$ \\
\hline 5 & Banana Plantlets & $36,243,379$ & 760,000 & $35,483,379$ \\
\hline 6 & Tree seedlings & $49,720,423$ & 483,000 & $49,237,423$ \\
\hline 7 & Maize seeds & $36,952.1$ & $1,787.5$ tons & 35,165 \\
\hline 8 & Beans & $73,488.1$ & $1,309.6$ tons & 72,179 \\
\hline 9 & Cassava Cuttings & $2,790,840$ & 80,000 bags & $2,710,840$ \\
\hline 10 & Cattle (Dairy) & $13,507,700$ & 5,321 heads & $13,502,379$ \\
\hline 11 & Cattle (Beef) & 5,709 & 390 heads & 5,319 \\
\hline 12 & Pigs & $2,413,337$ & 2,106 & $2,411,231$ \\
\hline 13 & Goats & $3,262,880$ & 1,530 & $3,261,350$ \\
\hline 14 & Chicken & $37,799,473$ & 95 units of 500 birds & $33,915,889$ \\
& & & each=47,500 & \\
\hline
\end{tabular}

Source: NAADS secretariat, See also Ministry of defence and veteran affairs (n.d).

From the table, apart from tea seedlings which were distributed in excess of the quantity needed, the other inputs were very small compared to what NAADS ought to have distributed.

In our specific case study (Masheruka town council), we documented input distribution for the August/September, 2017 planting season. However, inputs were very small compared to the total number of households in the town council.

Table 3. Input distribution for August/September 2017 Season

\begin{tabular}{l|l|l}
\hline S/N & Item & Quantity \\
\hline 1 & Mango seedlings & 1500 seedlings \\
\hline 2 & Apples & 2000 seedlings \\
\hline 3 & Beans & $1400 \mathrm{kgs}$ \\
\hline
\end{tabular}

Source: Field data

Masheruka town council with a population of 13,731 people (District Profile) and 36 villages/cells ${ }^{4}$ (approximately 2,880 households), it would mean that 1,958 or more households are in subsistence farming (target of OWC). As such, the town council receives limited quantities for such a big number of people. Additionally, by 2017, Sheema district as a whole had received 167 heifers (District Records, 2017). These heifers are very few to cover a district of 207, 343 people and 45, 812 households (UBOS, 2016).

${ }^{4}$ Each village has approximately 80-100 households according to local council chairmen. 
Farmers identified a number of issues in regard to the challenge of limited quantities supplied as below;

The quantities are small but even the distribution mechanism is poor. First comers are given $10 \mathrm{kgs}$ of beans and late comers are given half $(1 / 2)$ a kilogramme. It's unfair, we should be given equal quantities so that everybody gets (female farmer).

I was given one mango seedling. Is this what President Museveni says will take us out of poverty by 2020 ? (male farmer).

From the above assertions, we note that inputs supplied are small. We, however, established that for cash crops (especially coffee), many farmers had not picked them due to lack of enough land, yet this is where government puts emphasis. It's, however, important to note that Sheema North is predominantly a banana growing and cattle rearing place with limited or no free land. For instance, the 2014 population and housing census established that in Sheema North, $91.0 \%$ of the people were engaged in crop growing where $70.5 \%$ grew Matoke (bananas), $80.1 \%$ grew beans and only $18.3 \%$ grew coffee (cash crop) while $58.7 \%$ were keeping livestock (UBOS, 2016). This clearly demonstrates that cash crops are given less attention but as we established, the problem is limited land.

Why do they bring much of what we don't want and less of what we want?

You ask for 100 seedlings of coffee and they give you 300 seedlings. We

don't have land for coffee but for food crops such as beans, we can intercrop them with bananas (male farmer).

The quotation above reveals that farmers in Masheruka town council are not interested in coffee or cash crops in general since they have limited or not free land where to plant the crops.

Apart from the problem of limited quantities, some of the farmers also complained about the quality of the inputs supplied.

Some of the ginger distributed by OWC sometime back failed to germinate while our local one does well. They give us poor quality inputs (male farmer).

Discussions with a village (LCI) chairman revealed that even the heifers that OWC is distributing are of poor quality compared to what many farmers in the area rear and wondered why NAADS couldn't procure the cows from within the district instead of buying them from outside the district. He argued that some of the heifers looked sickly and poor quality not the Friesian cows they were promised.

OWC distributes poor quality heifers and buys them from outside Sheema. Our cows here are far better than what they supply. Why can't they buy from within our district? I think they go for cheap ones to make profit (LCI chairman).

Related to limited quantities and poor quality inputs, we established that these inputs (especially seeds, seedlings and other planting materials) are in most cases delivered late (past planting season). This pushes farmers with already planned gardens to resort to their own saved seeds from the previous harvest(s). 
OWC seeds delay. I prepared my garden for beans they had promised but I ended up planting my own seeds (female farmer).

In FY 2016/2017 as district leaders, we rejected 4-6 lorries of maize seeds and some bags of Irish potatoes because they were delivered towards a dry season. I hear they were taken to another district (Senior district official).

This indicates that the problem of late deliveries is rampant and disrupts farmers' planting schedules and ultimately production levels. However, officials at NAADS secretariat reasoned that the problem is brought about by the long procurement process and at times delays in disbursement of funds from Ministry of finance.

\subsubsection{Stringent Entry Requirements}

It was established that some of the entry requirements set up by MAAIF are unaffordable by subsistence farmers. This is largely in cases where animals such as heifers and pigs are involved. The MAAIF, standing orders of procedure for OWC (2015a) clearly states that livestock production requires adequate infrastructure, knowledge, skills, land and financial capability and therefore eligible beneficiaries must have housing structure and land for pasture, adequate knowledge on feeding, health management, record keeping and entrepreneurial skills to market the products (p.22).

heifers must be given to those who can handle them and have experience in rearing cows but not to everyone. These are Friesian cows and can easily die under poor conditions. We need to identify someone with experience and have some ability and capacity to buy some animal drugs in case the cow falls sick but also one with a constructed shed. He must also have planted some Napier grass for the cow (Senior district official).

This illustrates clearly that subsistence farmers may not easily qualify for heifers simply because they lack the financial capacity, the skills and land where to plant grass for the $\operatorname{animal}(\mathrm{s})$.

Additionally MAAIF, Standing orders of procedure for OWC (2015a), shows that beneficiaries to OWC programme should demonstrate interest, availability of enough land and readiness. By putting emphasis on land, the programme did not put into consideration the cultural aspects governing land in Uganda. For instance, women though part of the family cannot make important decisions regarding family land. Women may for instance not grow cash crops on the land without spousal consent.

\subsubsection{Long Distances to Walk for Inputs}

Distribution of OWC inputs in Uganda is done at the sub county/town council level. This was the same case with our study area though we established that in some instances, planting materials (e.g. coffee) are taken up to the parish level. However, for food crops and livestock, distribution is strictly done at the sub county/town council. The distance to travel disadvantages the weak (e.g. the elderly, the disabled and the sick). As we observed, distribution is done on first come, first served basis and this disadvantages people from far off 
villages. By the time they reach the distribution point, inputs are either finished or very little is remaining.

Women in distant areas are largely disadvantaged and especially those with no money. While men ride bicycles and others use hired motor cycles, poor women have to walk $3-4 \mathrm{~km}$ for inputs. By the time they reach, they find supplies finished and they miss out (LCI Chairman).

By distributing inputs at the sub counties and town councils, the programme did not put into consideration the issue of vulnerable groups such as the disabled and the elderly. As a result, they miss out in most cases because we give to whoever is here (town council official).

\subsubsection{Poor Information Flow Regarding Inputs Delivery and Distribution}

Our findings revealed that information flow under OWC is still a big challenge. First, NAADS secretariat is never specific on delivery dates to the district(s).

We have had poor information flow with the suppliers as they simply dump inputs without our knowledge. We just see them delivering but as district leaders, we must receive and distribute to farmers. They have minimally involved us as district leaders (district official).

Moreover farmers as well have limited information about input delivery. Discussion with OWC officials in the district revealed that information for programme implementation is aired on Radio West. We established that in towns or trading centres, public loud speakers are used to disseminate OWC information. However, this is largely done for cash crop deliveries especially coffee. Other inputs (such as for food security-beans, maize and livestock) are never publicized. Instead, publicity is done by word of mouth amongst farmers. This implies that many would-be beneficiaries are likely to miss out.

We established that information flow is at times limited by finances. The village and town council leadership lacks resources and/or facilitation to mobilize farmers when inputs are delivered. These leaders at times have to use their mobile phones to inform farmers but with no clear budget. Facilitation for mobilization is the responsibility of DLGs. According to MAAIF, Standing orders of procedure for OWC (2015a), the district chairperson and the Chief Administrative officer (CAO) should mobilize local resources to support OWC input delivery and beneficiary ascertainment.

The district leaders can call you at any time irrespective of where you are to mobilize farmers for inputs but we too have our own programmes. Remember they don't give any facilitation but expect you to act on a very short notice. We therefore inform a few farmers we manage to access (LCI chairman).

Discussions with OWC officials in the district further revealed that through 'barazas' (public gatherings) organised by area MPs and village meetings, OWC message is also given. However, such information is general and is never specific on input delivery dates. Also, 
these gatherings are exclusionary to those who don't attend and therefore miss out on vital information.

I don't know anything about OWC. I hear they distribute coffee but nobody has ever told me or interested me in it. I would be happy to also benefit from the programme because I am a farmer and I have land. Unfortunately, they never call us in their meetings"(opposition politician).

Our LCI chairman is discriminative. He informs only those around him and those of his class leaving many of us out of the programme (female farmer).

Discussions with the OWC spokesperson at the national level revealed that the district leadership is expected to inform farmers for inputs. However, at the national level, he noted that OWC has an active social media account (Facebook account) and a website where programme information is shared. Unfortunately, we note that such a channel of communication is for the elites and not suitable for majority farmers. For instance, in Sheema North, the percentage number of people of 10 years and above accessing internet are $4.4 \%$ while those between 18-30 years are 9.4\% (UBOS, 2016).

\subsubsection{Elite Capture}

Our findings revealed that elites (especially political elites) are using their positions to benefit more from the programme than the intended beneficiaries. At the town council, OWC officials (UPDF) are quite often absent when distributions are ongoing. This is because they are few in number (only two in the district) and cannot be at all distribution points. As such, politicians (especially local councilors) help in the distribution process. These politicians at times take advantage of the absence of OWC officers to take inputs for themselves claiming they are also farmers. Our observations for instance revealed a senior town council official who loaded his car with a sack of mango seedlings when many farmers had missed. At district level, councilors (LCV) were also seen distributing apple seedlings amongst themselves. However, a senior district official justified this saying they are also farmers and had requested the inputs from him through the district production officer (DPO).

\subsubsection{Top-Down Approach in Selection of Priority Crops and Beneficiaries}

Although MAAIF, Standing orders of procedure for OWC (2015a) advocates for a bottom-up approach in the selection of priority crops for DLGs and selection of beneficiaries, we established that OWC is using a top-down approach and farmers are never consulted on what to be supplied. Every year, the NAADS secretariat compiles a data base of the priority commodities to be supported under the commodity approach for each DLG based on both national priority commodities and district specific priority commodities. For the FY 2016/2017, 2017/2018 and 2018/2019, a maximum of nine national and district specific priority commodities in line with the commodity approach were to be supported. As such, all district local governments were required to submit the nine priority commodities by ranking with the projected quantities for the medium term (2016/2017, 2017/2018. 2018/2019) to the NAADS secretariat by $30^{\text {th }}$ September 2015 (MFPED, 2015). 
However, we established that in identifying the priority crops for the district, farmers were never consulted. Instead district leaders decided on what they thought were the district priority commodities (interview with a senior district official, 2017). In most cases, the district leaders feel they are in a better position to determine what is good for their district. The leaders we talked to reasoned that NAADS secretariat does not facilitate such a process and therefore, the district is constrained financially to do a district needs assessment but importantly, they know what the district priorities are. This implies that there is a possibility of delivering what farmers don't need.

For us in Sheema, we are basically banana growers and cattle keepers. We would expect OWC to supply us organic fertilizers or give us money to buy these fertilizers but they instead bring coffee seedlings, yet we don't have land (male farmer).

In regard to the selection of beneficiaries, MAAIF, Standing orders of procedure for OWC (2015a) stipulates that beneficiaries should be identified at the village level, screened at sub county/town council level and forwarded to the district for approval. This should be done at the beginning of every planting season. We established that the local leadership has been instrumental in fulfilling this requirement but as farmers showed, the story normally challenges at distribution time where they have to re-register and the earlier registers are ignored.

They registered us according to what we could manage; some registered for coffee, cows, pigs and others for chicken. But to our surprise, when these things came, the leaders didn't follow the registers. Others who registered could miss out while those who didn't register got the inputs (female farmer).

The above statement clearly shows that farmers do not get what they had registered and requested for. According to the town council leadership, the changes are determined by the quantities they receive and the new comers who join.

\subsubsection{Involvement of the Army (UPDF) in OWC Programme}

Although President Museveni employed the army to supply inputs under OWC, a cross section of our respondents felt the army was misplaced as they do not possess the technical expertise to handle agriculture. We established that farmers fear military men (OWC officials) and this scares away the would-be beneficiaries.

These army men are feared. Even in district meetings, some of these ladies cannot confidently raise issues concerning their operations. Even the DPO fears them. If the district leaders can fear them, what of our farmers? (former district leader).

I am a National Resistance Movement (NRM) chairperson for this town council but I can't question a military colonel on anything. What if he slaps me (NRM leader). 
The above statements clearly show that OWC officials (UPDF) are still feared by most farmers and this might compromise the working relationship between them. However, officials at OWC secretariat stressed that the army is a disciplined force and as an institution, they have a disciplinary mechanism for their officers. Because of this, there is no reason why farmers should fear them. In addition, most of the deployed OWC officers are 'sons and daughters' of those districts.

\subsubsection{Monitoring of the Programme}

Our findings revealed that there was no monitoring of the programme. OWC officers supervise the delivery of inputs but they don't monitor whether farmers have put them to correct use. As such, some of the inputs delivered are never planted and they go to waste, others are poorly tendered and they die out. For instance, a senior district official informed us that the programme had lost two cows in Sheema south constituency because of lack of monitoring.

NAADS officials revealed that the district leadership and the area MPs are supposed to monitor the programme. However, district officials claimed that they are not fully involved in the programme and since no money from OWC comes to the district (except inputs), they lack funds for monitoring. According to MAAIF (2015b), funds utilized for inspection, monitoring and evaluation under the production and marketing grant (PMG) should be used to support the local government mandate under OWC. However, the PMG grant is insufficient to ensure adequate service delivery given that the wage bill is approximately equivalent to the operational funds (ibid).

The area MPs we talked to stressed that OWC has not involved leaders and therefore leaders cannot monitor what they don't know.

OWC has not fully involved us in this programme. They just bring inputs to the district without our knowledge and expect us to monitor. Where do we begin? Good enough, as an MP, Iam allocated some share which I collect directly from NAADs that I distribute to my people and that is what I can monitor" (MP).

\section{Discussion}

Our findings have demonstrated that OWC programme in Masheruka town council is facing a big challenge of limited quantities supplied, which implies that many farmers either take little or miss the inputs. This affects the programme's overall goal of enhancing household participation in commercial agricultural production. This finding is corroborated by the Parliament of Uganda report on OWC (2017) which stressed that the quantities supplied under OWC are usually small. However, the problem of limited quantities as the study has shown is largely attributed to limited government budget for the agriculture sector in general and NAADS secretariat in particular. Govere et. al (2009) note that massive government participation in input distribution is not sustainable due to limited government budget. Also, while there was a challenge of limited supplies, there was also a problem of proper coordination and needs assessment. In some areas, seedlings were put to waste because OWC supplied what was not needed. 
Related to limited quantities is the challenge of poor quality inputs. Some of the inputs (e.g. ginger) had failed to germinate in some places and heifers supplied were of poor quality than what farmers had expected. MFPED (2014b) notes that some districts are not sufficiently involved in verifying inputs delivered in the country to the farmers. The Report of the Auditor General on agriculture/NAADS (2016) had unearthed similar challenges namely that in some districts, the heifers distributed under OWC programme were sickly, resulting into beneficiary farmers incurring excessive costs on treatment. The implication is that poor quality inputs is not a problem limited to Masheruka town council alone but it's a country wide problem.

Additionally, while inputs were poor quality and limited, they were delivered late-a phenomenon that pushed farmers to plant their own saved seeds from the previous harvests. A baseline report on farmers' access to seed and other planting materials established that about $89 \%$ of the farmers obtain seeds from informal sources majorly from their own saved seeds (ISSD, Uganda, 2014) or through sharing amongst themselves within the community (Ogang, 2014) whereas others buy from local markets. This therefore means that farmers do not over rely on government seeds that are delivered late but have many other viable alternatives. Importantly, there is untimely distribution of inputs associated with delayed procurements and delayed release of funds in Uganda (MFPED, 2014b).

Further, poor communication between the suppliers, DLG and beneficiaries or farmers has also curtailed the smooth implementation of OWC programme. NAADS secretariat after receiving requisitions from DLGs doesn't inform them on specific delivery dates. This keeps the district leadership and the farmers in waiting unsure whether inputs will be delivered or not. A similar problem was established by the Agriculture Sector Annual Monitoring Report 2014/2015 namely that there was poor distribution of inputs due to late communication from NAADS secretariat about delivery dates.

Important also, OWC programme grapples with the challenge of long distances farmers have to walk to pick inputs. According to the Equal Opportunities Commission report (2016), since OWC was designed to benefit all, no arrangements were put in place to ensure that all the disadvantaged groups benefit from the programme. This is further corroborated by Hailu, Kassa and Kibrom (2014) in their study in Ethiopia which established that distance to the nearest market was negatively related with adoption of both chemical fertilizer and high yielding varieties (HYVs) and statistically significant at 5\% and $1 \%$ level of significance respectively.

The involvement of the army (UPDF) in OWC is also a challenge to many farmers although the programme designers feel it's a blessing. Ugandans are not used to working with security forces in agriculture but President Museveni deliberately deployed the army for smooth supervision and delivery of inputs. Lowe and Sanyu (2017) note that the army since 2014 was charged with distributing inputs to Uganda's farmers without any agricultural expertise. However, in justification of the army's role in Agriculture, OWC officials stressed that the army basically focuses on logistics (e.g. seed distribution) and not on advising, planting and technical agricultural elements. They too possess discipline, integrity, passion and 
accountability and armies world over are vanguards of economic development (Ntambirweki-Karugonjo \& Emma, 2015).

We also note that in Masheruka town council, OWC programme has been captured by the elites (especially political elites) who distribute inputs amongst themselves claiming they are also farmers. The problem is however not limited to Masheruka town council alone. In Mukono district, the government spokesperson, Mr. Ofwono Opondo was reported to have benefited from OWC when he took for himself a heifer. However, an uproar from district councilors made him to return it (Sabano \& Kisekka, 2017).

Moreover, OWC programme's entry requirements do not favour certain categories of farmers. For instance, by emphasizing land as a basic requirement, women and the youth were never given due consideration since either they don't have land or cannot make important decisions regarding family land. For instance, MFPED (2017) noted that OWC programme lacked appropriate mechanisms for dealing with gender inequalities partly associated with limited access to land and advisory services by women; male dominance in decision making in the use of family land.

Lastly, although MAAIF, Standing orders for OWC (2015a) stipulate a bottom-up approach, the process has turned top-down especially in selection of priority crops and beneficiaries. Equal Opportunities Commission (2016), further states that farmer selection is a bit top-down from district to sub-county and community level hence may breed some form of discrimination especially based on political opinions/affiliation. Furthermore, the top-down farmer selection limits participation, is biased, lacks ownership and is vulnerable to elite capture.

\section{Conclusion}

OWC programme though was introduced to address the weaknesses identified in the predecessor programme- NAADS and commercialize agriculture may not easily achieve the intended goal if the challenges hampering its full implementation are not addressed. The most common challenges such as small quantities supplied due to budget constraints, poor inputs and late deliveries, poor information flow and elite capture need urgent attention. The introduction of the army in programme implementation has been received with mixed reactions by sections of the public with farmers expressing discomfort working with the army while the programme designers feel the army will easily bring out the needed successes. Government needs to address these challenges by increasing agriculture budget, improving communication between suppliers, district leadership and farmers but also improving on the quality of inputs supplied. Monitoring the programme is too vital but also engaging extension workers as opposed to army men.

\section{References}

Akkaya, D., Bimpikis, K., \& Hau, L. (2016). Agricultural supply chains under government interventions. Unpublished manuscript. 
Angina, C. (2017, June). Operation wealth creation is progressing. Operation Wealth Creation, 001(001), 1-72.

Baltzer, K., \& Hansen, H. (2011). Agricultural input subsidies in Sub-Saharan Africa. Evaluation study, 2011/2. Retrieved from https://www.oecd.org/derec/49231998.pdf

Balya, C. (2010). Supporting smallholder farmers to grow in Uganda: The story of Eagle Lager (Power point slides). Retrieved from http://www.value-chains.org/dyn/bds/docs/

Benin, S., Nkonya E., Okecho, G., Pender, J., Nahdy, S., Mugarura, S., Kato, E., \& Kayobyo, G. (2007). Assessing the impact of NAADS in Uganda Rural livelihoods (IFPRI Discussion paper No. 00724). Retrieved from International Food Policy Research Institute website: http://ebrary.ifpri.org/utils/getfile/collection/

Brodeur, C., \& Clerson, F. (2015). Is government intervention in Agriculture still relevant in the $21^{\text {st }}$ century? (Final Report presented to UNION DES PRODUCTEURS AGRICOLES). Retrieved from Momagri website: http://www.momagri.org/UK/focus-on-issues/Government-intervention-in-agriculture-

Chirwa, E. W., Matita, M., \& Dorward, A. (2011). Factors influencing access to agricultural input subsidy coupons in Malawi (FAC Working paper No. 027). Retrieved from Future Agricultures website: http://www.ndr.mw:8080/xmlui/bitstream/handle/1234

Civil Society Budget Advocacy Group (CSBAG). (2017). What MPs should consider when debating the agriculture budget 2017/2018. (Agriculture sector position paper on the Uganda National budget framework paper 2017/2018). Retrieved from http://csbag.org/wp-content/uploads/2017/02/CSOs-Agriculture-

Clark, S., \& Thompson, S. (2011). Advancing a policy dialogue: Policy context and rationale for intervention in the Agri-food sector. Retrieved from The Canadian Agri-food policy institute website: https://capi-icpa.ca/pdfs/2011/CAPI_Viability1_Context.pdf.

Development Research and Training (DRT). (2012). Agriculture and small scale producers in Uganda: Issues, Challenges and Options for policy. Policy brief, Trocaire. Retrieved from http://www.drt-ug.org/wp-content/uploads/2016/11/Agriculture-and-small-scale-producers-in -Uganda.pdf.

Equal Opportunities Commission. (2016). Annual Report on the state of equal opportunities in Uganda, 2015/2016. Kampala, Uganda: Author.

Gordon, A. (2000). Improving smallholder access to purchased inputs in sub-Saharan Africa. (Policy series No. 7). The University of Greenwich, Natural Resources Institute.

Govere, I., Foti, R., Mutandwa, E., Mashingaidze, A. B., \& Bhebhe, E. (2009). Policy perspectives on the role of government in the distribution of agricultural inputs to farmers: Lessons from Zimbabwe. International NGO Journal, 4(10), 470-479. 
Hailu, B. K., Kassa, B. A., \& Kibrom, A. W. (2014). Adoption and impact of agricultural technologies on farm income: Evidence from southern Tigray, Northern Ethiopia. International Journal of Food and Agricultural Economics, 2(4), 91-106.

ISSD Uganda. (2014). Baseline report on farmers' access to seed and other planting materials. Integrated seed sector development programme in Uganda. Retrieved from https://www.researchgate.net/publication/306259954_Baseline_Study_on_

Jelic, M. A., Jasminka, M. D., Srecko M. R., \& Jugoslav, A. (2014). Reasons for government intervention in Agriculture. Annals of the University of Oradea, 3, 174-179. https://doi.org/10.15660/AUOFMTE.2014-3.3060

Ladua, M. I. (2015 September 7). Operation wealth creation to streamline coordination. Daily Monitor. Retrieved from http://www.monitor.co.ug/Business/

Lowe, A., \& Sanyu, F. (2017). Creating opportunities for young people in northern Uganda's agricultural sector. (Overseas Development Institute Report). Retrieved from https://www.odi.org/sites/odi.org.uk/files/resource-documents/11676.pdf

Masaba, M. C. (2014, March). Enabling environments for fostering agriculture investments conducive to poverty reduction, gender equality and food security: A case of the oil palm public private partnership in Uganda. Paper presented at the Multi-stakeholder Conference on Agricultural Investment, Gender and Land in Africa. Towards Inclusive Gender Equitable and Socially Responsible Investment. Retrieved from http://www.plaas.org.za/sites/default/files/Parallel9\%20Masaba.pdf

Ministry of Agriculture, Animal Industry and Fisheries (MAAIF). (2015a). Standing orders of procedure for operation wealth creation. Kampala, Uganda.

Ministry of Agriculture, Animal Industry and Fisheries (MAAIF). (2015b). Local government budget framework paper, FY 2016/17. Agriculture sector issues paper, August 2015, Entebbe, Uganda.

Ministry of Agriculture, Animal Industry and Fisheries (MAAIF). (2015c). Policy statement for Ministry of Agriculture, Animal industry and Fisheries for the financial year 2015/16. Retrieved from http://budget.go.ug/budget/sites/default/files/Sector\%20.

Ministry of Defence and Veteran Affairs. (n.d) Operation wealth creation. Retrieved from http://portal.defence.go.ug:10039/wps/portal/mod-home/welfare/Operation-Wealth-

Ministry of Finance, Planning and Economic Development (MFPED). (2014). Distribution of Agricultural inputs in Uganda: What are the key challenges? (Briefing paper, 8/14, 2014). Budgeting, Monitoring and Accountability Unit. Kampala, Uganda.

Ministry of Finance, Planning and Economic development (MFPED). (2015). Agriculture sector: Annual Monitoring Report FY 2014/2015. Retrieved from http://mambosms.ug/Data/atha/finance/dmdocuments/Agriculture 
Ministry of Finance, Planning and Economic Development (MFPED). (2017). Semi-annual budget monitoring report, FY 2016/2017. Retrieved from http://budget.go.ug/budget/sites/default/files/National\%20Budget\%20doc

Mugasi, S. (2017 June). NAADS contribution to the transformation Agenda. Operation wealth Creation, 001(001), 1-72.

Mutami, C. (2015). Smallholder Agricuture production in Zimbabwe: A survey. Consilience: The Journal of sustainable development, 14(2), 140-157.

Mvula, P. M., Chirwa, E. M., Matita, M., \& Dorward, A. (2010). Challenges of access to farm input subsidy by most vulnerable groups in Malawi. Evaluation of the 2010/11 farm input subsidy. Retrieved from http://wadonda.com/Mvula_et_al_2011_FISP10_

Ntambirweki, K., \& Jones, E. (2015). Transformation of agriculture for wealth creation: Involvement of UPDF in NAADS programme and its effectiveness (Advocates Coalition for Development and Environment, Info sheet, No.33). Retrieved from ACODE website: http://www.acode-u.org/Files/Publications/infosheet_33.pdf

Office of the Auditor General (OAG). (2016). The Report of the Auditor General on the financial statements of NAADS programme for the year ended $30^{\text {th }}$ June 2016. Kampala, Uganda.

Ogang, C. (2014). Access to inputs for Smallholder farmers in Africa (Power point slides). Retrieved from https://www.fertilizer.org/en/doc_library/Knowledge\%20Resources

Okoboi, G., Kuteesa, A., \& Barungi, M. (2013). The impact of the NAADS programme on household production and wealth in Uganda (Africa Growth Initiative Working Paper No. 7). Retrieved from The Brookings Institution website: https://www.brookings.edu/wp-content/uploads/

Oluka, H. B. (2016 July 13). Counting the cost of NAADS failure. The observer. Retrieved from http://www.observer.ug/news-headlines/

Operation Wealth Creation (OWC). (n.d). Retrieved from http://owc.co.ug/

Parliament of Uganda. (2017). Report of the sectoral committee on agriculture of Parliament on the implementation of the OWC programme in Uganda, May 2017. Kampala, Uganda.

Pazvakavambwa, S. (2009). Achieving Household and National Food Security in Zimbabwe. A-MDTF initiative, Harare- Zimbabwe.

Rwakakamba, M., \& Lukwago, D. (2014). The changing face of NAADS and what the entry of Uganda people's defence forces will mean for Uganda's agriculture (Agency for Transformation, Public policy issue paper No.004). Kampala, Uganda.

Sabano, J., \& Kisekka, C. (2017 July 26). Government spokesman returns wealth creation cow after uproar. The Daily Monitor. Retrieved from http://www.monitor.co.ug/News/National/Government. 


\section{Macrothink}

Schiesari, C., Mockshell, J., \& Zeller, M. (2006). Farm input subsidy programme in Malawi: The rationale behind the policy (MPRA paper No. 81409). Retrieved from https://mpra.ub.uni-muenchen.de/81409/1/MPRA_paper_81409.pdf

Semujju, I. N. (2017 May 24). Why Saleh's wealth creation is collapsing. The observer. Retrieved from http://www.observer.ug/viewpoint/53019

Smith, L., Fowler, M., Mugerwa, F., Ogeda, M., \& Akroyd, S. (2007). Uganda: Agriculture sector Public expenditure review, phases 1 and 2. Retrieved from http://siteresources.worldbank.org/INTRESPUBEXPANAAGR/Resources

Uganda Bureau of Statistics (UBOS). (2016). The National Population and Housing Census. Kampala, Uganda: Author.

Wandulu, J. A. (2004). Facilitating agriculture input distribution in Uganda: Experiences based on activities conducted by AT Uganda Itd. Uganda Journal of Agricultural sciences, 9 , 758-765.

Wiggins, S., \& Brooks, J. (2010 November). The use of input subsidies in developing countries. Paper presented at the Global forum on Agriculture. Retrieved from https://www.oecd.org/tad/agricultural-policies/46340359.pdf

World Bank, (2016). Agriculture: A driver of growth and poverty reduction. Retrieved from http://www.worldbank.org/en/country/uganda/publication/

\section{Copyright Disclaimer}

Copyright for this article is retained by the author(s), with first publication rights granted to the journal.

This is an open-access article distributed under the terms and conditions of the Creative Commons Attribution license (http://creativecommons.org/licenses/by/4.0/). 